\title{
Analysis on the Character of Clyde in $A n$ American Tragedy by Tripartite Personality Structure Theory
}

\author{
Jiang Zhu \\ School of Foreign Languages, Changchun University of Science and Technology, Changchun, China \\ Email: zhujiang98@163.com \\ Yuxiao Bao \\ School of Foreign Languages, Changchun University of Science and Technology, Changchun, China \\ Email: baoyuxiao2005@yahoo.com.cn
}

\begin{abstract}
An American Tragedy, written by Theodore Dreiser, is an important novel in the history of American literature. In this novel, Dreiser models the hero Clyde and reveals the reason of his tragic life. This paper will analyze Clyde's character by Freud's tripartite personality structure theory. In this way we will understand Clyde's character much better and realize that if a person cannot resist the temptations on the road of pursuing his dream, he will destroy himself like Clyde.
\end{abstract}

Index Terms - Clyde, id, ego, superego, tripartite personality structure theory

\section{INTRODUCTION}

Theodore Dreiser is a famous American writer in the first half of the $20_{\text {th }}$ century. An American Tragedy, which was published in 1925, is considered his masterpiece. In this novel, Dreiser analyzes the reason of the hero Clyde's crime, and mentions that Clyde's tragedy is not only his own tragedy, but the tragedy of American society. This paper will analyze Clyde's character by Freud's tripartite personality structure theory.

\section{Freud's Tripartite Personality Structure Theory}

In the $19_{\text {th }}$ century, along with the popularization of individualism and complexity of social life in modern western countries, western literature, especially western novels presented a tendency in which the individual destiny and mentality received more and more care. The complexity and contradiction of characters' mentality were emphasized gradually. Psychological description has gradually become a basic approach to model characters since then.

At the beginning of the $20_{\text {th }}$ century, Sigmund Freud is the one who impacted greatly on western philosophical circle among the great thinkers. After World War I, his theories have shocked philosophy, literature, art, religion, social prevailing customs and moral and ethics. Nowadays, these theories are still employed in sociology, aesthetics, anthropology, pedagogy, law and mythology. Freud is a famous psychologist and psychiatrist with dense philosophical qualities. His works are abundant, especially the famous psychoanalysis theory with significant theoretical meanings. Freud's psychological analysis theory is a theory researching on individual personality structure and its internal conflict and can be generally divided into instinct theory, tripartite personality structure theory and psychological anatomy.

Freud's psychological analysis theory is a break-through to the concept of binary opposition of humanistic reason and sensitiveness in traditional philosophy with a division of personality structure into three levels and clarification of their interactive relationship. His theory smashes the rationalistic myth of "human are rational animals" through the reveal and emphasis of ego. It is an overturn and renovation of traditional western theory of human nature.

\section{A. The Origin of Tripartite Personality Structure Theory}

Psychological analysis, also named psychoanalysis, is not only one of the most important genres of modern western psychology, but also one of the most influential critical approaches to literature and literary theory schools in the $20_{\text {th }}$ century. Like other theories, psychological analysis did not appear without reasons. It is an inheritance and development to ideas and theories of former psychologists.

Psychological analysis was born under comprehensive influences of natural science and the humanities of the $19_{\text {th }}$ century. It is an innovation of natural science and results of humanities of former scientists. Freud inherited some related theories including Darwin's evolution theory, psychology and modern physics. In short, the achievements of natural science in the $19_{\text {th }}$ century had changed the cognition of human beings about themselves thoroughly and made them survey themselves again after the divine glory given by God faded. They began to treat themselves as one of the 
things of the natural world. Freud is no doubt a beneficiary in this age and an heir of scientific heritage. These scientific achievements became firm foundation of natural science for Freud's researches on unconsciousness psychology.

Besides the inheritance to some related theories, the other condition for the generation of psychological analysis is the promotion of unconsciousness theory by Freud. Thus it can be seen that the exploration to "unconsciousness" of European philosophers and romantic writers of early times is the important theoretical source of Freud's unconsciousness theory. Freud, himself, also pointed that poets and philosophers before him had discovered unconsciousness, and what he found was just the scientific way to research on unconsciousness (Freud, 1962).

Freud was engaged in researches on neurology in his early ages and treated mental diseases by hypnotism. During that process, psychological analysis was gradually developed. Freud also discovered and affirmed the mental phenomenon of unconsciousness. He proposed that dreams are satisfaction of desires and shaped the analytical technology of dreams. A new field of study on spirit and spiritual pathological phenomena was created when The Interpretation of Dreams was published in 1900. In 1914, Freud found that autophilia is a kind of psychological phenomenon. In 1920, Freud revised the theory about motivation of instincts and proposed death instinct as supplement. In 1923, Freud published his thesis Ego and Id, in this thesis, he made corrections and complement to his early psychological structure theory based on unconsciousness theory and sexual instinct theory. He put forward theory of personality structure and divided human's personality structure into three layers: id, ego and super-ego. That is the origin of tripartite personality structure theory.

\section{B. The Connotation of Tripartite Personality Structure Theory}

Freud perfected his theory in the later stage of his ideology, proposed in a systematic way and clarified his famous tripartite personality structure theory in details.

1. Id

According to Freud's tripartite personality structure theory, human's id, gained through heredity, is the most primitive and unconscious part of psychological structure. At the bottom of personality structure, id is constituted of inherited instincts and desires. It is the source of human's enthusiasm, instincts and habits. It is only dominated by natural law and physiological law, instead of being restrained by all exterior elements such as logic, reason and social conventions. Id performs the first principle of life (the pleasure-principle), which means that there is not any value or moral that can define id. The goal of id is to pursue happiness, avoid suffering, lessen strained experience of pain and discomfort as far as possible and seek the individual comfort and content. Its only need is to satisfy itself no matter what way it adopts. As a result, it can not be allowed by both regular will and various kinds of social criterion and can not be depressed frequently. Human body is taken as a source of energy of id. When energy is released, two basic kinds of instincts of human beings are activated. They are instincts of survival and death. When the energy of id is blocked in the process of its release, the id will endeavor to break through from the obstructions and make it released from fantasy. As a result, dreams are formed in this process.

Id is irrational. It will send out orders continuously to fulfill the own will (to gain happiness). Impetuous, selfish, unsocial and pleasure-orientated are its features. In addition, if desires of id can not be satisfied in a short time, a primary process will be stimulated to eliminate the nervous state. This primary process can be imagination, megrim, dreamland, etc.. Freud also believes that id will ultimately be restrained by reality and be transited into a self state. It is proved that the transition from the pleasure-principle to the reality-principle is the most important progress in the process of self-development. In the evolution of personality, the id will inevitably bow to the reality to achieve a balance of personality.

2. Ego

Ego lies in the middle layer of personality structure. In tripartite personality structure theory, situated between id and external world, ego is a part of id which is differentiated and developed under the influence of consciousness system. Ego accommodates the imbalance between demands of instincts and the real world. Ego, the product of society, belongs to consciousness. It follows the reality-principle and makes accommodation between id and realistic environment, which means it performs under reasonable and logical principle. Ego manages and oppresses id in accordance with the demands of external world to achieve a result of taking advantages and eliminating disadvantages. It will depress and store stuff that can not be admitted by society into unconsciousness for preventing an open conflict with social morals. The reality-principle pursues postponed, reduced happiness which is fit with reality, rather than deny the pleasure-principle. The ultimate goal is trying hard to meet the demands of avoiding pain and directing to joy. The relationship between ego and id is compared to that between a knight and his horse. The control of ego to id is presented as that of knight to a horse, and the unruly nature is a symbol of untamed passion.

As a part of id, ego represents reason and common sense. It is influenced and bounded by regulations of external world and presents external world for id. Ego plays as a pacifier to adjust the relationship of id, ego and super-ego. On one hand, it is the representative of demands of external world and hopes to become loyal servant of id; on the other hand, the super-ego which represents social behavioral regulations monitors id. Ego will be punished and will be in a nervous and ashamed situation when id violates these behavioral rules. So, ego is induced by id, regulated by super-ego and condemned by the reality. It performs as a servant of these three masters. It makes great efforts to reduce and adjust the pressure on its shoulder for achieving a harmonious state in some degree.

3. Super-ego 
Lying in the top layer of personality structure, super-ego is the moralized ego. It stands for requires of morality and justice. It pursues perfection and ideal instead of happiness or reality, which embodies regulations and standards of taboos, morals and ethics, and religious rules and punishments. Super-ego can be divided into self-ideal and conscience. The former appears as a kind of moral criterion and standard; while the latter means that behaviors which violate moral standards must be punished. It is a major function for super-ego to instruct ego in oppressing impulsions of id and correct behaviors deviating or violating moral criterion and ideal with a sense of compunction or guilt continuously.

Freud believes that the responsibility of super-ego is to preserve social standards and behavioral criterion. Super-ego can also be called as "paragon of ego". It takes conscience and self-ideal as its core and follows the morality-principle. It pursues a moral state of perfection. Super-ego has the power of dominating and guiding instinct to suppress its impulsion including human's libido (sexual desire) and attacking desire. Super-ego strives to prevent the energy of instincts from being released directly under impulsive action and satisfaction of desires, or indirectly released from self mechanism. Contrasting with id and ego, the instruction of super-ego to instincts is prohibition and it strains every nerve to interrupt performances of the pleasure-principle and the reality-principle. Super-ego employs conscience and moral imperative to restrain id and administrate ego for maintaining execution of social criterion and stability of society. But, id and the impulsion of ego can not be fully covered by super-ego. In Freud's opinion, this perfect personality state is just an ideal and it is not possible to be realized. Id and ego will get rid of super-ego by every means, so that under some condition, super-ego has to yield to demands of instincts.

\section{The Characteristics of Tripartite Personality Structure Theory}

Freud believes that personality itself is a dynamic energy system consisting of id, ego and super-ego. They interact via a certain mechanism and impact on thoughts and behaviors of human under influences of external environment when they are in a relative stable harmonious state, in which process a complete personality is formed. When there is a severe triangular conflict and they can't make an inter-coordination and balance, as a result, the whole personality energy system will be in chaos and people will suffer psychopathy. Due to different influences of id, ego and super-ego, individuals will display diverse personal qualities, thoughts, words and deeds in social range and interpersonal relationship and cause various contradictions and conflicts. However, a harmonious and balanced state will be reached in the end.

\section{The Relationship among Id, Ego and Super-ego}

Id, ego and super-ego interact and against each other instead of being isolated and separated from each other. Id is the most active dynamic element. The most profound essence of human lies in primary and spontaneous instinctive power. These powers are the same to all individuals and they point to satisfaction of certain innate demands. Super-ego instructs ego to try its best to restrict the impulse of id; while ego makes every effort to reconcile the two extreme counteracting forces in order that human can be normal people. It should be mentioned that, although Freud's tripartite personality structure theory and all of his psychological analysis theories have not been proved completely, the widely recognized marvelous theories could reveal all connotation of human's psychosocial behaviors correctly in some degree. It is helpful for us to grasp all behaviors and psychological activities of characters more detailed and make analysis of characters.

Freud also believes that id, ego and super-ego lie in different levels of consciousness. The correlations among them have constituted the complex structure of personality dynamics. The similarity between super-ego and ego lying in one part of them is contained in consciousness and the other part is contained in subconsciousness. Id is completely contained in the field of subconsciousness. Like ice in water, the subconsciousness lies at the margin between unconsciousness and consciousness. Consciousness is the part which is above the water surface while unconsciousness is that which is deeply hidden under the water surface. With the ups and downs of ice, the personality structure maintains a dynamic balance.

\section{Clyde’s Tripartite Personality Structure and Its Reflection}

Clyde is the hero of Dreiser's novel An American Tragedy. By analyzing Clyde's character, we will know the reason of his tragic end. The analysis of Clyde's character is based on Freud's tripartite personality structure. His behaviors and final destiny are closely related to the proportion of three parts in his personality mechanism.

\section{A. The Indulgent Id}

According to Freud, the way for id to satisfy its need is an impulsive behavior, which means to satisfy immediately. For example, people should let off anger without delay and get food when one is hungry (Freud, 1962). They behave out of instincts, without considering possible consequences. Lying in the bottom of personality structure, id is inherent like human body. It is in the deep layer of subconsciousness, consisting of countless natural instincts of human, just like a large pot of boiling and turbulent excitements. The pursuit of instinctive impulses and satisfaction of repressed desires are aims of id.

Clyde is the captive of his own desires. The desire to fulfill sex impulse is one part of id, which is presented through his behaviors. Clyde prefers sensory stimulations and romances but with a rather poor ability of self-control. He always 
visits brothels although he believes that it is degenerated and guilty. His id gains the upper hand of personality structure so it is hard for him to restrain the desires of sensory stimulations. In the novel, Dreiser describes Clyde's psychological state like this: "All of a sudden he felt faint thrills of hot and cold racing up and down his back and all over him. His hands and face grew hot and then became moist_ — then his cheeks and forehead flamed. He could feel them. Strange, swift, enticing and yet disturbing thoughts raced in and out of his consciousness. His hair tingled and he saw pictures_bacchanalian scenes_—which swiftly, and yet in vain, he sought to put out of his mind. They would keep coming back. And he wanted them to come back. Yet he did not" (Dreiser, 2000). This psychological state presents a struggle between his id and ego. Clyde could abreact momently and does not need to take any responsibility, which becomes one of his spiritual depositum. While actually, this depositum is based on a wispy mirage.

The first manifestation of Clyde's id is his infatuation on Hortense, a sophisticated and snobbish girl. Clyde dreams to have sexual relationship with her and his ego could not restrain the temptation of carnal desire. His normal emotions are squeezed out of his soul. He conceals his income and savings to his family and buys an expensive fur-coat for Hortense by borrowing money in order to get the satisfaction of lust for id. At the same time, his sister is badly in need of money because she is abandoned by her lover and is going to give birth to a child. His mother asks him for 50 dollars, while he lies to her claiming that he does not have so much money. Actually he plans to pay for Hortense's favorite fur-coat. In this scene, there is a drastic conflict between sexual desire of instinct and conscience. On one side is the girl whom he is eager to make relationship with, on the other side is his sister who is in need of help. Dreiser portrays the response of Clyde and his furious intrapsychic conflict and struggle vividly. "How terrible it was not to help her. How could he refuse her, really? Nervously he licked his lips and passed a hand over his brow, for a nervous moisture had broken out upon his face. He felt strained and mean and incompetent under the circumstances" (Dreiser, 2000). This is another proof to prove that it is difficult for Clyde to control his instinct. This is maybe the first time for Clyde to lie for this troublesome matter. Although his id takes the upper hand, there is still a little conscience and ethics left. His spirit wanders and struggles between sexual passion and conscience in his deep heart and subconsciousness. Finally, impulses of id become the master of ego. But, to soothe his guilty conscience, Clyde gives his mother five dollars. It seems as a compromise between his id and super-ego. Clyde also realizes that he is indecent and mean to do like that and worries that he will be punished for his shameful deeds. This is the first conflict in Clyde's personality mechanism of id, ego and super-ego. The conflict results from Clyde's pursuit of sexual instinct. Needs of id are temporarily satisfied by ego under realistic conditions. Morality mechanism of super-ego is so weak that Clyde's psychology couldn't achieve a balance state morally.

When Clyde comes across his uncle and grasps the chance to become a head of department in his uncle's factory, his repressed instinctive desires emerge again. Due to the failure in having sexual relationship with Hortense, he has to search another substitute in order to release his libido. The innocent Roberta becomes another id entity or target for sexual desire of Clyde's personality mechanism. The sexual drive is so powerful that his ego descends to the servant of id once again. To achieve his aim, Clyde allures Roberta to secretly date with him frequently. The ego in reality temporarily meets the demands of id with the premise of not creating greater pains.

If the infatuation on Hortense in Clyde's teenager age could just be regarded as the beginning of desires of id in his personality mechanism, the appearance of Roberta is a prelude of his instinctive desires. The one who stimulates his desires to the extreme is Sondra, who is the individual entity represented by sexual desire, passions, money and social status. She is the ladder which can take Clyde to the top status of society and gain success. Dreiser's excellent psychological description skills are presented in An American Tragedy (Hu, 1995). Existence in real life and reflections of human are contained in imaginations, illusions and dreams of heroes. There is such a dream to show the struggle between the hero's id and super-ego. When Roberta becomes the obstacle in Clyde's relationship with Sondra, he plans to make her disappear forever. During that period, he has a nightmare. In his dream, the crowds of ferocious vipers symbolize the desire of id to kill Roberta; while the horned beast symbolizes super-ego which tries to depress and prevent the evil desire from being carried out. Eventually, evil instinctive desires unfortunately dominate the ego in reality again (Howe, 1964). On purpose or not, Clyde clears the obstacle away and satisfies desires of id. His tragic destiny is also doomed eternally at the same time.

\section{B. The Lost Ego and Looming Super-ego}

Ego follows the principle of reality. It adjusts the relationship between id and the outer world according to realistic conditions and objective environment and satisfies needs of id with the premise of not creating greater pains. Different from impulsive behaviors of id, the way for ego to satisfy itself is to delay actions in order to think and solve problems. It serves for the reality-principle and works out a plan for the action, then acts according to the plan. According to Freud's theory, the relationship between ego and id is just like that between a rider and a horse. Freud (1962) believes that the horse provides energy for marching while the rider holds the right for deciding directions and commanding the horse. Sometimes unreasonable situation will happen; the rider must guide the horse according to the direction which the horse advances. Ego impels behaviors of human more reasonable other than do whatever one wants as id. It demands the subject to control one's behaviors for adapting to the surroundings.

Clyde is not an inborn fish-blooded man. Sometimes his ego emerges and functions in his consciousness. When his sister Esta is in her difficult situation, Clyde is also in a critical period with Hortense. Whether he should help Esta out of the dilemma, he thinks it over and over. "But, he now thought, there was Esta in her wretched room awaiting the 
most unhappy result of her one romance. How was she to make out, he asked himself, even in the face of the fact that he feared to be included in the financial problem which Esta as well all the family presented" (Dreiser, 2000). When he cheats his mother that he doesn't have enough money with him, there is strong struggle in his deep heart, "He suffered a pang of commingled self-commiseration and self-contempt, based on the distress he felt for his mother. He could not bring himself to think of losing Hortense. He must have her. And yet his mother looked so lone and so resourceless. It was shameful. He was low, really mean. Might he not, later, be punished for a thing like this?" (Dreiser, 2000) At that time, Clyde loses his innocent nature. He may hate himself as readers do. But his ego is still defeated by his id and serves for id inevitably. Finally, his sister's life-saving money turns into a favorite fur-coat for Hortense.

In the second part of the novel, after the car accident, Clyde begins to live an incog life. He strolls and does many humble jobs in different places. For the fear of being arrested, he abides by the law and behaves himself. During this period, the powers of id, ego and super-ego in Clyde's personality achieve a relative and temporary peaceful state, which means that his id is depressed by ego under the supervision of super-ego. Clyde's various instinctive impulses not suitable for social life pattern are depressed and super-ego becomes the master of ego. All of this is proved in this period. Actually, Clyde is not free from the supervision of super-ego completely. After he flees from Kansas, he misses his family very much, especially his mother. He regrets for what he has done and mails part of his income to the family. He writes to his mother telling her that he behaves well for a long time (Rubinstein, 1988). Obviously, it proves Freud's theory: when ego makes mistakes driven by id, super-ego will instruct id to do something as punishment or compensate to pursue a psychological or moral balance. Clyde's super-ego functions in such a fragile and looming way that the peaceful state can not last long and instinctive desires are just depressed temporarily.

In the last part of the story, it seems that the super-ego functions once again. Clyde evaluates his deeds seriously and regrets for what he has done to poor Roberta. But it is too late. The revival of consciousness can not prevent him from death penalty. To sum up, Clyde is a combination of id, ego and super-ego. If we compare the personality mechanism into a battlefield among id, ego and super-ego, super-ego is defeated thoroughly. His id takes the upper hand and dominates his behaviors. As a result, Clyde's tragic fate is unavoidable.

\section{CONCLUSION}

In the previous part, Clyde's character is analyzed by Freud's tripartite personality structure theory. By analyzing Clyde's character, we can realize that on the road of pursuing one's dream, a person will inevitably face various temptations and most of which are full of original impulses and kinds of desires of id. If he can resist them firmly, it will be easier for him to gain real success. Otherwise, like Clyde, he will not only fail, but also destroy himself. So, it is rather important to make one's ego serve for the super-ego and the reality and control his id properly. Besides, he should make efforts for pursuing his dream on condition that what he does is legal and moral. Only in this way could the innocent human nature and the initial self be maintained in the prosperous and blatant world.

\section{REFERENCES}

[1] Dreiser, T. (2000). An American Tragedy. New York: Signet Classic.

[2] Freud, S. (1962). The Ego and the Id. New York: Norton.

[3] Howe, I. (1964). Dreiser and Tragedy: The Stature of Theodore Dreiser. New York: The World Publishing Company.

[4] Hu Yintong et al. (1995). A Course in American Literature. Tianjin: Nankai University Press.

[5] Rubinstein, A. T. (1988). American Literature: Root and Flower. Beijing: Foreign Language Teaching and Research Press.

Jiang Zhu was born in Changchun, China in 1971. He received his M.A. degree in English from Changchun University of Science and Technology, China in 2003.

$\mathrm{He}$ is currently an associate professor in School of Foreign Languages, Changchun University of Science and Technology. His research field is English and American literature.

Yuxiao Bao was born in Taian, China in 1986. She received her M.A. degree in English from Changchun University of Science and Technology, China in 2012. Her research field is English and American literature. 